\title{
Pengaruh Model Pembelajaran Kooperatif TGT dan Pembelajaran Berbasis Audiovisual Terhadap Passing Bawah Bolavoli
}

\author{
Oleh : Akhmad Aji Pradana* \\ ajiblek.id@gmail.com
}

\begin{abstract}
The purpose of this study was to analyze the effects of TGT cooperative learning and audiovisual media based learning model on volleyball forearm pass skill learning outcome. Method used in this research was quasi experimental design with pretest-posttest approachment. Instrument used in this study were portofolio assessment approach on volleyball forearm pass skill. The result showed that the implementation of TGT cooperative learning model have shown an increased learning output on volleyball forearm pass skill (27.64\%), meanwhile the implementation of learning model using audiovisual media have shown an increased learning output on volleyball forearm pass skill (34.78 \%). Based on the result, it was concluded that the implementation of audiovisual media based learning model have shown better improvement on volleyball forearm pass skill learning output.
\end{abstract}

Keywords: TGT Cooperative learning model, audiovisual media based learning model.

*Akhmad Aji Pradana adalah dosen Prodi PGMI Sekolah Tinggi Ilmu Tarbiyah Maakhdum Ibrahim Tuban

\section{PENDAHULUAN}

Tenaga pendidik merupakan komponen utama dalam pelaksanaan proses pembelajaran di sekolah, oleh karena itu kompetensi seorang tenaga pendidik juga sangat mempengaruhi ketercapaian tujuan pembelajaran. Salah satu peran penting seorang guru dalam pembelajaran di sekolah adalah sebagai fasilitator dalam mencapai keberhasilan belajar siswa untuk memenuhi beberapa kompetensi dasar pada kurikulum. Dalam mencapai hasil belajar siswa yang optimal dibutuhkan beberapa strategi, Syah (2009, p.133) menjelaskan, strategi dan pendekatan belajar, serta metode belajar merupakan faktor yang menentukan tingkat efisiensi dan keberhasilan belajar siswa.

Olahraga bolavoli merupakan salah satu materi pembelajaran yang termasuk dalam kategori permainan bola besar dan merupakan salah satu kompetensi dasar yang harus dicapai dalam mata pelajaran pendidikan jasmani olahraga dan kesehatan (PJOK) pada jenjang sekolah menengah pertama di Indonesia. Beberapa model pembelajaran yang cocok diterapkan pada pembelajaran PJOK materi bolavoli dan direkomendasikan oleh beberapa hasil penelitian sebelumnya adalah model pembelajaran kooperatif TGT dan model pembelajaran melalui media audiovisual. Hasil penelitian Aswara (2012, p.77) menunjukkan 
bahwa terdapat peningkatan yang signifikan akibat penerapan model pembelajaran menggunakan media audiovisual terhadap hasil belajar keterampilan passing bawah bolavoli dengan peningkatan rata-rata sebesar $31.62 \%$. Sedangkan hasil penelitian Hakim (2010, p.60) menunjukkan bahwa terdapat peningkatan yang signifikan pada rata-rata skor hasil belajar passing bawah bolavoli siswa yang mengikuti model pembelajaran kooperatif tipe TGT.

Dari beberapa hasil penelitian sebelumnya, penulis merasa tertarik untuk mengetahui model pembelajaran yang lebih cocok untuk diterapkan dalam pembelajaran keterampilan passing bawah dalam permainan bolavoli. Oleh karena itu tujuan dalam penelitian ini adalah untuk menganalisis apakah dengan menerapkan model pembelajaran kooperatif TGT dan model pembelajaran melalui media audiovisual dapat meningkatkan hasil belajar keterampilan passing bawah bolavoli, serta untuk menganalisis adakah perbedaan penerapan model pembelajaran kooperatif TGT dengan model pembelajaran melalui media audiovisual terhadap hasil belajar keterampilan passing bawah bolavoli.

Penjelasan mengenai model pembelajaran kooperatif TGT (Team Games Tournament) menurut Huda (2014, p.197) merupakan salah satu tipe pembelajaran kooperatif yang dikembangkan untuk meningkatkan skill dasar, kerjasama, dan interaksi positif antar siswa dalam menguasai materi pembelajaran. Sedangkan menurut Suyatno (2009, p.54), model pembelajaran kooperatif tipe TGT merupakan metode dimana siswa memainkan permainan dengan anggota-anggota tim lain untuk memperoleh tambahan poin untuk tim mereka.

Maksud dari arti kata Teams Game Tournament adalah permainan kompetisi yang dilakukan secara berkelompok. Jadi model pembelajaran kooperatif kompetisi ini cenderung kearah kompetisi antar kelompok heterogen yang disusun berdasarkan kemampuan, gender, dan karakter dari masing-masing siswa.

Huda (2014, p.197) menjelaskan, prosedur pelaksanaan model pembelajaran kooperatif TGT: setiap anggota ditugaskan mempelajari materi terlebih dahulu bersama anggotanya, selanjutnya mereka diuji secara individual melalui permainan. Nilai yang mereka peroleh dari permainan akan ditotal dan menentukan skor kelompok mereka masing-masing. Suyatno (2009, p.54) menambahkan bahwa, penerapan model ini dengan cara mengelompokkan siswa secara heterogen, memberikan tugas pada masing-masing kelompok, setiap kelompok bekerja sama dalam bentuk kerja individual dan diskusi.

Di era globalisasi seperti sekarang ini, penggunaan media tidak dapat dilepaskan dari kehidupan manusia terlebih lagi pada usia perkembangan. Hal tersebut dipertegas oleh pendapat Roberts $(2008$, p.11) bahwa, They spend more time with media than any single 
activity other than sleeping, with the average eight to eighteen years old reporting more than six hours of daily media use. Pengertian media menurut Arsyad (2014, p.3) adalah, perantara yang mengantar informasi antara sumber dan penerima.

Sedangkan menurut Sadiman (2006, p.7), media adalah segala sesuatu yang dapat digunakan untuk menyalurkan pesan dari pengirim ke penerima. Lebih fokus mengenai media dalam ruang lingkup pembelajaran dijelaskan oleh Arsyad (2014, p.10) bahwa, media pembelajaran adalah segala sesuatu yang dapat digunakan untuk menyampaikan pesan atau informasi dalam proses belajar mengajar sehingga dapat merangsang perhatian dan minat siswa dalam belajar.

Dari beberapa kutipan di atas dapat dipahami bahwa media pembelajaran merupakan suatu sarana penghubung yang berfungsi menyampaikan informasi dan merangsang minat kepada siswa dalam melaksanakan proses pembelajaran.

"Media audiovisual adalah jenis media yang mengandung unsur suara dan gambar yang bisa dilihat, misalnya rekaman video, berbagai ukuran film, slide suara, dan lain sebagainya." (Sanjaya, 2007, p.74). Sementara Arsyad (2014, p.91) mengemukakan bahwa media berbasis audiovisual merupakan media visual yang menggabungkan penggunaan suara (audio) serta beberapa naskah narasi untuk menggambarkan atau memvisualisasikan materi pembelajaran.

Berdasarkan dari beberapa uraian di atas, dapat disimpulkan bahwa model pembelajaran melalui media audiovisual merupakan model pembelajaran yang pelaksanaannya memanfaatkan media audiovisual sebagai penunjang untuk meningkatkan minat siswa dalam proses pembelajaran.

\section{METODE}

Jenis penelitian yang digunakan adalah penelitian deskriptif kuantitatif dengan pendekatan metode Quasi Experimental Design (eksperimen semu). Metode tersebut dipilih karena keterbatasan peneliti yang tidak dapat mengontrol secara keseluruhan variabelvariabel luar yang secara langsung maupun tidak langsung mempengaruhi subjek penelitian.

Penelitian ini bertujuan untuk mencari pengaruh perlakuan model pembelajaran kooperatif TGT (X1) dan model pembelajaran melalui media audiovisual (X2) terhadap hasil belajar keterampilan passing bawah bolavoli (O). Maka desain yang digunakan merupakan pretest-posttest control group design, akan tetapi pada desain ini kelompok eksperimen maupun kelompok kontrol tidak dipilih secara random.

Penelitian dilaksanakan pada tanggal 1 - 25 Agustus 2016 di Sekolah Menengah Pertama Shafta Surabaya dan menggunakan keseluruhan jumlah populasi sebagai subjek penelitian sehingga penelitian ini disebut juga sebagai penelitian populasi (Population Research). 
Subjek penelitian dalam penelitian ini adalah siswa kelas 7B SMP Shafta Surabaya yang dengan jumlah 41 siswa. Selanjutnya seluruh subjek penelitian diberikan pre-test sebagai acuan untuk pembagian kelompok berdasarkan pendekatan ordinal pairing. Setelah dilakukan ordinal pairing, kelompok-kelompok tersebut diundi lagi secara random sebanyak dua kali untuk menentukan kelompok eksperimen dan kelompok kontrol serta kelompok yang mendapatkan perlakuan model pembelajaran kooperatif TGT maupun model pembelajaran melalui media audiovisual.

Karena penelitian ini berada dalam ruang lingkup pembelajaran, maka data yang dibutuhkan berupa rekapitulasi nilai perkembangan hasil belajar siswa, Oleh karena itu teknik pengumpulan data dalam penelitian ini menggunakan pendekatan penilaian portofolio. Prosedur pelaksanaan penilaian portofolio yang dijelaskan Sudijandoko $(2008$, p.6) adalah,

"Dalam pelaksanaan penilaian portofolio salah satu yang disarankan adalah melalui observasi tentang kemampuan siswa selama pembelajaran. Kegiatan yang diobservasi dirangkum berdasarkan indikator tiap-tiap kompetensi, pengamatan dilakukan untuk setiap pertemuan. Alat pengamatan mengunakan lembar check list berisi daftar kegiatan yang dijabarkan dari indikator sesuai kompetensi yang akan dicapai. Kompetensi dan indikator dapat dilihat dalam silabus dan atau guru dapat merumuskan sendiri, diresmikan dengan kondisi dan situasi (konteks) siswa dan sekolah."

Selanjutnya, rumus yang digunakan dalam penilaian portofolio seperti yang dijelaskan oleh Hakim (2010, p.46) adalah sebagai berikut :

$$
\mathrm{NA}=\sum \frac{\sum N i \times \text { Bobot }}{\sum \text { Qi } \times \text { Bobotmaks }} \times 100
$$

Dari rumus di atas dapat dijabarkan bahwa NA merupakan nilai akhir siswa, $\sum$ Ni adalah Jumlah nilai individu yang dinilai dalam sekali pertemuan, sedangkan $\sum$ Qi merupakan jumlah indikator yang digunakan sebagai acuan penilaian. Beberapa indikator yang digunakan dalam penilaian portofolio pada penelitian ini adalah sebagai berikut :

Tabel 1. Indikator Penilaian Keterampilan Passing Bawah

\begin{tabular}{|c|c|c|c|}
\hline I. POSISI KAKI & $\begin{array}{l}\text { II. POSISI } \\
\text { LENGAN }\end{array}$ & $\begin{array}{l}\text { III. PERKENAAN } \\
\text { BOLA }\end{array}$ & $\begin{array}{l}\text { IV. SIKAP } \\
\text { LANJUTAN }\end{array}$ \\
\hline $\begin{array}{l}\text { Kaki dibuka } \\
\text { selebar bahu }\end{array}$ & $\begin{array}{l}\text { Siku agak } \\
\text { ditekuk }\end{array}$ & $\begin{array}{l}\text { Pergelangan tangan } \\
\text { sampai siku }\end{array}$ & $\begin{array}{l}\text { Kaki belakang } \\
\text { melangkah ke depan }\end{array}$ \\
\hline
\end{tabular}




\begin{tabular}{|c|c|c|c|}
\hline $\begin{array}{l}\text { Posisi kaki } \\
\text { diagonal/ sejajar }\end{array}$ & $\begin{array}{l}\text { tangan } \\
\text { berdekatan }\end{array}$ & $\begin{array}{lr}\text { Gerakan } & \text { lengan } \\
\text { disesuaikan } & \text { dengan } \\
\text { keras/lemah } & \text { kecepatan } \\
\text { bola } & \\
\end{array}$ & $\begin{array}{l}\text { Posisi kaki } \\
\text { selebar bahu }\end{array}$ \\
\hline $\begin{array}{l}\text { Lutut } \\
\text { ditekuk }\end{array}$ & $\begin{array}{ll}a & \text { ibu jari } \\
\text { ar } & \end{array}$ & $\begin{array}{l}\text { Ayunan } \\
\text { maksimal } \\
\text { bahu }\end{array}$ & $\begin{array}{l}\text { Posisi } \\
\text { diluruskan }\end{array}$ \\
\hline $\begin{array}{ll}\text { Ujung } & \text { kaki } \\
\text { menghadap } & \text { arah } \\
\text { bola datang } & \\
\end{array}$ & $\begin{array}{lr}\text { Posisi } & \text { lengan } \\
\text { rileks dan tidak } \\
\text { kaku }\end{array}$ & $\begin{array}{l}\text { Arah pantulan bola } \\
\text { membentuk lintasan } \\
\text { parabola }\end{array}$ & $\begin{array}{l}\text { Posisi ayunan leng } \\
\text { mengikuti at } \\
\text { pantulan bola }\end{array}$ \\
\hline
\end{tabular}

Kriteria Penilaian :

Nilai A, apabila memenuhi 4 indikator yang ditunjukkan

Nilai B, apabila memenuhi 3 indikator yang ditunjukkan

Nilai C, apabila memenuhi 2 indikator yang ditunjukkan

Nilai D, apabila memenuhi 1 indikator yang ditunjukkan

Data nilai akhir siswa yang telah terkumpul selanjutnya akan dianalisis dengan bantuan software Statistical product and service solutions (SPSS) versi 17. Teknik analisis data yang digunakan antara lain: (1) analisis deskriptif berupa penghitungan rata-rata dan persentase peningkatan pretest-posttest; (2) Uji hipotesis komparatif berupa T-test untuk sampel sejenis mengetahui perbedaan antara hasil pre-test dan post-test pada subjek penelitian yang diberi perlakuan dan T-test untuk sampel berbeda untuk membandingkan hasil rata-rata subjek penelitian yang diberi perlakuan model pembelajaran kooperatif tipe TGT dengan subjek penelitian yang diberi perlakuan model pembelajaran melalui media audiovisual.

\section{HASIL PENELITIAN DAN PEMBAHASAN}

Pada penelitian ini, perlakuan model pembelajaran kooperatif TGT diberikan pada kelompok eksperimen 1, sedangkan perlakuan model pembelajaran melalui media audiovisual diberikan pada kelompok eksperimen 2 untuk mengetahui pengaruhnya masingmasing terhadap peningkatan hasil belajar keterampilan passing bawah bolavoli. Hasil analisis ditunjukkan pada grafik di bawah: 
Gambar 1. Grafik Perbandingan Peningkatan Hasil Belajar antara

Model Pembelajaran Kooperatif TGT dengan Model Pembelajaran

Melalui Media Audiovisual

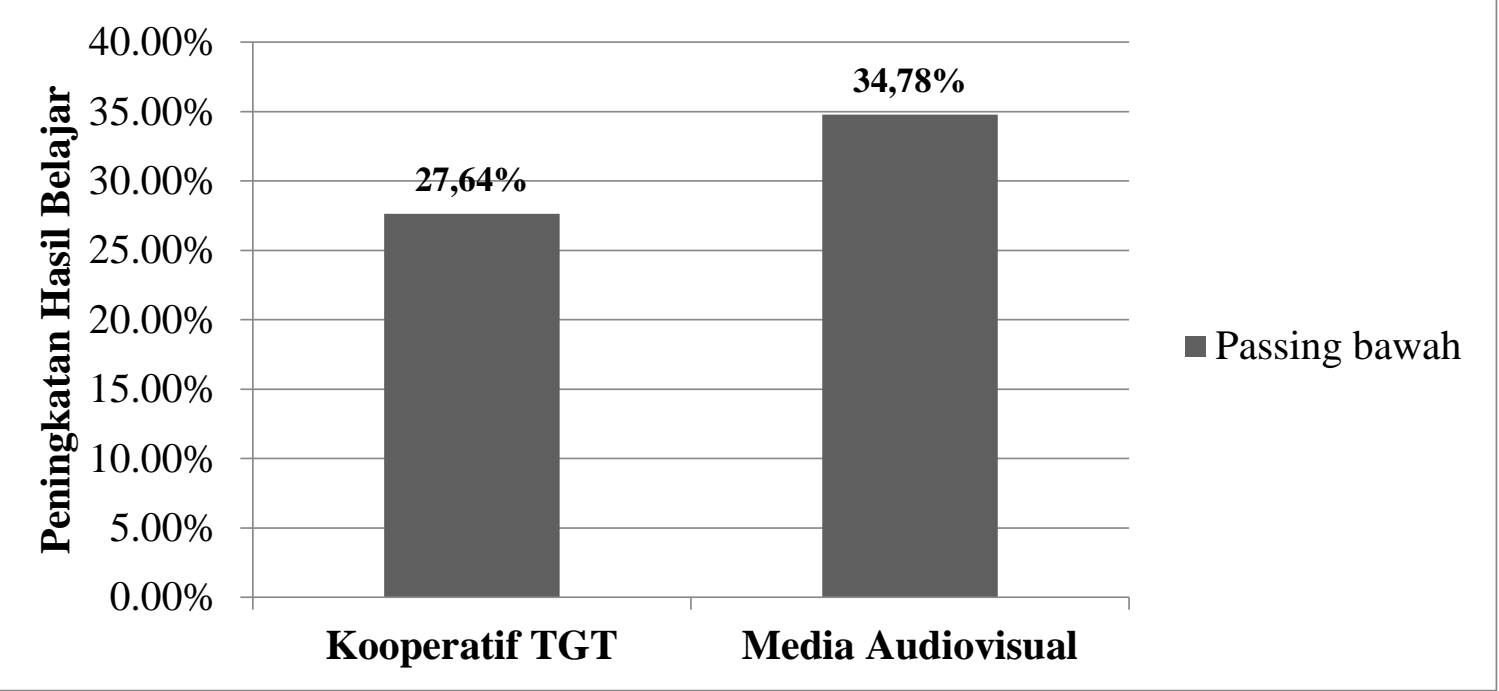

Grafik di atas menunjukkan bahwa penerapan perlakuan model pembelajaran kooperatif TGT memberikan peningkatan yang signifikan terhadap hasil belajar keterampilan passing bawah bolavoli sebesar $27,64 \%$. Hasil tersebut sesuai dengan beberapa hasil penelitian sebelumnya, seperti hasil penelitian Hakim (2010, p.60) menunjukkan bahwa terdapat peningkatan yang signifikan pada rata-rata skor hasil belajar passing bawah bolavoli siswa yang mengikuti model pembelajaran kooperatif tipe TGT; hasil penelitian Purnomo (2011, p.23) yang menjelaskan bahwa model cooperative learning menghasilkan hasil belajar siswa lebih baik daripada model pembelajaran konvensional; Gull (2015, p.252) yang menyatakan bahwa, Cooperative learning when using as instructional strategy has positive effect on students academic achievement.; serta Altun (2015, p.463), The cooperation based learningteaching environment provided opportunities to be successful, contributed to the development of social and personal skills.

Hasil pengamatan di lapangan menunjukkan bahwa sebagian besar siswa mengalami perkembangan positif dalam segi keterampilan maupun afektifnya, terutama kepercayaan diri dan interaksi antar siswa dalam kelompoknya. Hal tersebut sesuai dengan hasil penelitian Fatimah (2012, p.5) yang menjelaskan bahwa prestasi belajar siswa untuk ranah afektif pada kelompok sampel yang diberikan model pembelajaran kooperatif menunjukkan jumlah persentase sebesar 93\%. Selain itu, hal tersebut juga relevan dengan hasil penelitian Bayraktar (2013, p.33), “Cooperative learning method theoretically enhances student's self confidence and success, improves the relationships between friends, and develops the skill of getting knowledge." 
Namun beberapa siswa yang belum terbiasa dengan implementasi model pembelajaran kooperatif TGT pada awalnya masih merasa minder dan kurang aktif dalam kelompoknya. Rasa kurang percaya diri tersebut biasanya muncul karena adanya tuntutan dalam kelompoknya yang mengharuskan setiap anggota mampu melakukan tugasnya masingmasing. Situasi tersebut sesuai dengan kelemahan model pembelajaran kooperatif TGT yang dikemukakan oleh Altun (2015, p.464), The disadvantage of the practice was found out to be the requirement to be successful for all group members. This situation is stated in two ways. First one is the anxiety of less successful students due to the group pressure. And the second is possible conflicts within and between groups.

Peran guru dalam kondisi tersebut sangat dibutuhkan untuk selalu mengamati setiap perilaku siswa dan memberikan bimbingan untuk mencegah konflik yang muncul pada kelompok belajar siswa. Seperti yang dijelaskan oleh Altun (2015, p.464), The instructors make good observations and be a guide in preventing and solving intragroup conflicts.

Selanjutnya berdasarkan gambar grafik di atas menunjukkan bahwa penerapan perlakuan model pembelajaran melalui media audiovisual memberikan peningkatan yang signifikan terhadap hasil belajar keterampilan passing bawah bolavoli sebesar 34,78\%. Hasil tersebut sesuai dengan beberapa hasil penelitian sebelumnya, seperti hasil penelitian Aswara (2012, p.77) yang menyatakan bahwa terdapat peningkatan yang signifikan akibat penerapan model pembelajaran menggunakan media audiovisual terhadap hasil belajar keterampilan passing bawah bolavoli; hasil penelitian Bire (2014, p.168), bahwa terdapat pengaruh yang signifikan gaya belajar visual, auditorial, dan kinestetik terhadap prestasi belajar; Mereuta (2013, p.1615), using audiovisual media in physical education class was able to improve Neuromotor and sensory-perceptual skills, thus ensuring the development of abilities and motor skills.; Sadegi (2013, p.214), given 5-weeks video modeling significantly improved the accuracy in handball shot.; serta hasil penelitian Zhao (2016, p.200), the use of network multimedia aided teaching system is of great help to the students master the technical movements, but also has a good effect on volleyball teaching.

Model pembelajaran melalui media audiovisual merupakan hal baru yang diterapkan dalam pembelajaran PJOK di sekolah target penelitian yang sebelumnya mengadopsi tipe model pembelajaran langsung yang terfokus pada guru. Sebagian besar siswa cukup antusias mengikuti model pembelajaran melalui media audiovisual karena hal tersebut dianggap unik dan berbeda dari pembelajaran PJOK pada umumnya. Hal tersebut sesuai dengan yang dijelaskan oleh Chen (2012, p.21), physical education multimedia teaching has very prominent effects on arousing students' sports motivation and enhancing their interest in 
exercises. Selain itu, pemahaman siswa mengenai rangkaian gerak keterampilan passing bawah bolavoli setelah penerapan model pembelajaran melalui media ausiovisual juga mengalami peningkatan dan cenderung lebih cepat. Penayangan rangkaian gerak keterampilan passing bawah bolavoli dalam gerak lambat sangat membantu siswa dalam mengamati secara detil setiap gerakan yang dianggap kompleks. Hal tersebut relevan dengan hasil penelitian Han (2015, p.1817) yang menjelaskan bahwa,

The multimedia CAI not only can each action through the slow camera way, and will a complex action into several parts, the teacher can according to each action one to explain. At the same time, each action can also be amplified, the students can clearly see every tiny detail of the movement, and thus grasp the essentials of action.

Berdasarkan grafik dan hasil pembahasan di atas dapat diketahui bahwa model pembelajaran melalui media audiovisual menunjukkan peningkatan hasil belajar keterampilan passing bawah bolavoli yang lebih besar daripada model pembelajaran kooperatif TGT. Hal tersebut dikarenakan dalam model pembelajaran melalui media audiovisual siswa dapat mengamati setiap detil gerakan dasar passing bawah bolavoli dengan lebih jelas jika dibandingkan dengan proses pengamatan pada model pembelajaran kooperatif TGT. Hal tersebut sesuai dengan hasil penelitian Sadegi (2013, p.215),

Using video model giving is one of the most common and effective methods in kinetic and physical education training; for, various techniques could be seen from different angles and by instructors help, the trainee will be able to analyze those movements thoroughly.

Serta hasil penelitian Han (2015, p.1817), the multimedia CAI not only can each action through the slow camera way, and will a complex action into several parts, the teacher can according to each action one to explain. At the same time, each action can also be amplified, the students can clearly see every tiny detail of the movement, and thus grasp the essentials of action.

Selain itu, minimnya peningkatan hasil belajar keterampilan passing bawah pada kelompok eksperimen 1 (model pembelajaran kooperatif TGT) disebabkan oleh kurangnya pendampingan guru selama proses pengamatan konsep gerak keterampilan keterampilan passing bawah bolavoli. Hal tersebut menunjukkan bahwa peran guru tetap dibutuhkan untuk membimbing dan mengarahkan selama proses pembelajaran pada model pembelajaran kooperatif TGT meskipun pada penerapan model pembelajaran kooperatif TGT lebih mengutamakan interaksi antar siswa dengan kelompoknya. Sesuai dengan yang dikemukakan 
Gillies (2009, p.938), given that teachers' discourses in classrooms are critically important as they provide students with insights on how to think and respond.

Berdasarkan pembahasan di atas, dapat diketahui bahwa penerapan model pembelajaran kooperatif TGT dan model pembelajaran melalui media audiovisual pada materi keterampilan passing bawah dalam permainan bolavoli mempunyai kelebihan dan kekurangan masingmasing. Kelebihan yang dapat diidentifikasi dari penerapan model pembelajaran TGT adalah kekompakan antar siswa dalam kelompoknya menyebabkan siswa merasa lebih nyaman untuk belajar dan berdiskusi bersama kelompoknya sehingga perkembangan siswa lebih merata. Sedangkan kelebihan pada penerapan model pembelajaran melalui media audiovisual, proses pengamatan materi keterampilan passing bawah bolavoli lebih menarik, jelas dan dapat diulang-ulang sehingga pemahaman siswa relatif lebih cepat.

Sementara itu, kekurangan yang dapat diidentifikasi dari penerapan model pembelajaran TGT adalah pada awal periode pembelajaran, proses pemahaman materi tergolong lambat karena beberapa siswa masih membutuhkan adaptasi dengan kelompok barunya. Sedangkan pada penerapan model pembelajaran melalui media audiovisual, kekurangan yang dapat diketahui adalah membutuhkan lebih banyak peralatan penunjang yang harus dipersiapkan seperti : laptop, LCD proyektor, kabel konektor, dll.

Berdasarkan penjelasan mengenai kelebihan dan kekurangan model pembelajaran kooperatif TGT dan model pembelajaran melalui media audiovisual, dapat disimpulkan bahwa kelebihan dan kekurangan kedua model pembelajaran tersebut secara tidak langsung mempunyai keterkaitan dan saling melengkapi satu sama lain. Oleh karena itu untuk menutupi kekurangan masing-masing model pembelajaran kooperatif TGT maupun model pembelajaran melalui media audiovisual dapat dilakukan dengan mengkombinasikan kedua model pembelajaran. Hal tersebut layak untuk dicoba dan dapat digunakan sebagai bahan untuk penelitian lebih lanjut mengenai pengembangan kombinasi model pembelajaran kooperatif TGT melalui media audiovisual untuk menyempurnakan kekurangan serta meningkatkan efektifitas kedua model pembelajaran tersebut.

\section{SIMPULAN}

Berdasarkan relevansi dari rumusan masalah, hasil penelitian, serta diskusi hasil penelitian, maka beberapa temuan dalam penelitian ini dapat disimpulkan bahwa model pembelajaran kooperatif tipe TGT dan model pembelajaran melalui media audiovisual dapat meningkatkan hasil belajar keterampilan passing bawah bolavoli. Disamping itu, pembahasan hasil penelitian juga menunjukkan bahwa model pembelajaran melalui media audiovisual 
menunjukkan peningkatan hasil belajar yang lebih baik pada materi keterampilan passing bawah dalam permainan bolavoli.

\section{DAFTAR PUSTAKA}

Altun, Sertel. (2015). "The Effect of Cooperative Learning on Students' Achievement and Views on the Science and Technology Course". International Electronic Journal of Elementary Education, 2015, 7(3), 451-468.

Arsyad, Azhar. (2014). Media Pembelajaran. Jakarta : Raja Grafindo Persada

Aswara, Yuda Agung. (2012). Penerapan Pembelajaran Menggunakan Media Audiovisual VCD Terhadap Hasil Belajar Passing Bawah dan Service Bawah Bolavoli. Tesis tidak diterbitkan. Surabaya : Pascasarjana Unesa

Bayraktar, Gökhan et al. (2013). "A Survey on Physical Education and Sport Department Students Opinion about Cooperative Learning Method". Journal of Education and Practice, Vol.4, No.22, pp. 30-34

Bire, A.L. (2014). Pengaruh Gaya Belajar Visual, Auditorial, dan Kinestetik Terhadap Prestasi Belajar Siswa. JURNAL KEPENDIDIKAN, Volume 44, Nomor 2, November 2014, Halaman 168-174

Chen, Qhiaoping. (2012). "Research for Influence of Physical Education Multimedia Teaching onSports Motivation of Students". Advances in information Sciences and Service Sciences (AISS) Vol. 4, Num. 16 pp. 14-22.

Fatimah, Siti. (2012). Pembelajaran Fisika Menggunakan Model Cooperative Learning Ditinjau Dari Prestasi Belajar Siswa. JURNAL KEPENDIDIKAN, Volume 42, Nomor 1, Mei 2012, Halaman $1-6$

Gillies, R.M. (2009). "Teachers reflections on cooperative learning Issues of implementation". Journal of Teaching and Teacher Education vol 26 (2010) pp. 933940

Gull F., Shehzad S. (2015). "Effects of Cooperative Learning on Students' Academic Achievement. Journal of Education and Learning”. Vol. 9(3) pp. 246-255.

Hakim, Luqmanul. (2010). Efektifitas Pembelajaran Passing Bawah Model Teams Games Tournaments Pada Bolavoli Mini dalam Pembelajaran Penjasorkes. Tesis tidak diterbitkan. Surabaya : Pascasarjana Unesa

Han, Yun. (2015). “Application of Multimedia CAI Technology in Physical Education”.The Open Cybernetics \& Systemics Journal, vol. 9, pp. 1814-1819.

Huda, Miftahul. (2014). Model-Model Pengajaran Dan Pembelajaran. Yogyakarta : Pustaka Pelajar 
Mereuta, Claudiu. (2013). "Psychomotor Stimulation of Students in Physical Education Using Audiovisual Media”. Procedia - Social and Behavioral Sciences vol.84 pp. 1611 1616

Purnomo, Y.W. (2011). Keefektifan Model Penemuan Terbimbing dan Cooperative Learning Pada Pembelajaran Matematika. JURNAL KEPENDIDIKAN, Volume 41, Nomor 1, Mei 2011, Halaman 23 - 33

Roberts, D. F., \& Foehr, U. G. (2008). “Trends In Media Use”. The Future of Children. Vol 18 No1, pp.11-37.

Sadegi, Nahid. et all. (2013). "Effects of video modeling on skill acquisition in learning the handball shoot”. European Journal of Experimental Biology, Vol 3 No 2, pp.214-218

Sadiman, Arief S, dkk. (2006). Media Pendidikan Pengertian, Pengembangan, dan Pemanfaatanannya. Jakarta : Raja Grafindo

Sanjaya, W. (2007). Strategi Pembelajaran Berorientasi Standar Proses Pendidikan. Jakarta: Kencana

Sudijandoko, Andun. (2008). Evaluasi Pendidikan Jasmani Dalam Pendekatan Portofolio, (Pelangi Ilmu vol. 2 no. 2). Surabaya : Unesa University Press

Suyatno, (2009). Menjelajah Pembelajaran Inovatif. Sidoarjo : Masmedia Buana Pustaka Syah, Muhibbin. (2009). Psikologi Belajar. Jakarta : PT Raja Grafindo Persada

Zhao, Yibo. (2016). "Study on the Application of Multimedia Network Teaching Platform in College Physical Education Teaching”. International Journal of Signal Processing, Image Processing and Pattern Recognition Vol.9, No.4, pp.193-202 